\title{
Evaluation of Nutritional and Medicinal Values of Edible Wild and Cultivated Pleurotus ostreatus ${ }^{\#}$
}

\author{
Sanem Bulam ${ }^{1, a, *}$, Nebahat Şule Üstün ${ }^{2, b}$, Aysun Pekşen ${ }^{3, c}$ \\ ${ }^{1}$ Department of Food Engineering, Faculty of Engineering, Giresun University, Güre Campus, 28200 Giresun, Turkey \\ ${ }^{2}$ Department of Food Engineering, Faculty of Engineering, Ondokuz Mayis University, Kurupelit Campus, 55139, Atakum/Samsun, Turkey \\ ${ }^{3}$ Department of Horticulture, Faculty of Agriculture, Ondokuz Mayls University, Kurupelit Campus, Atakum/Samsun 55139, Turkey
}

*Corresponding author

\begin{tabular}{l|l}
\hline A R T I C L E I N F O & A B S T R A C T \\
$\begin{array}{l}\text { "This study was presented as an oral } \\
\text { presentation at the 4th International } \\
\begin{array}{l}\text { Anatolian Agriculture, Food, } \\
\text { Environment and Biology Congress } \\
\text { Afyonkarahisar, TARGID 2019) }\end{array}\end{array}$ & $\begin{array}{l}\text { Because of its high nutritional value and pharmaceutical effects, oyster mushroom (Pleurotus } \\
\text { ostreatus (Jacq. ex Fr.) P. Kumm.) is collected from nature and cultivated in large scale. This } \\
\text { therapeutic mushroom is consumed as a functional food or food additive in soups, cereal and dairy } \\
\text { products, and commercially used in nutraceuticals and dietary supplements. The mycochemicals } \\
\text { including polysaccharides (crude fiber and } \beta \text {-glucans), essential amino acids, ergothioneine, } \\
\text { peptides, (glyco)proteins, lectins, phenolic compounds, polyketides (lovastatin), (tri)terpenoids, and } \\
\text { enzymes are naturally found in the fruiting bodies and mycelial biomass of } P \text {. ostreatus. The major } \\
\text { bioactive compounds concentration of this mushroom may be increased by modification of the } \\
\text { substrate composition and cultivation or postharvest conditions. The goal of this review is to evaluate } \\
\text { the results of the studies about the biochemical composition and medicinal properties of edible wild } \\
\text { and cultivated P. ostreatus. Furthermore, the advanced novel cultivation techniques, } \\
\text { biotechnological processes, and postharvest treatments were given in order to increase its nutritional } \\
\text { and nutraceutical values. }\end{array}$ \\
$\begin{array}{l}\text { Accepted : } 19 / 09 / 2019 \\
\text { Keywords: } \\
\text { Medicinal }\end{array}$ &
\end{tabular}

Nutraceutical

Food

Oyster mushroom

Pleurotus ostreatus

Türk Tarım - Gıda Bilim ve Teknoloji Dergisi 7(12): 2054-2061, 2019

\section{Yenilebilir Doğal ve Kültüre Alınmış Pleurotus ostreatus'un Besinsel ve Tıbbi Değerlerinin Değerlendirilmesi}

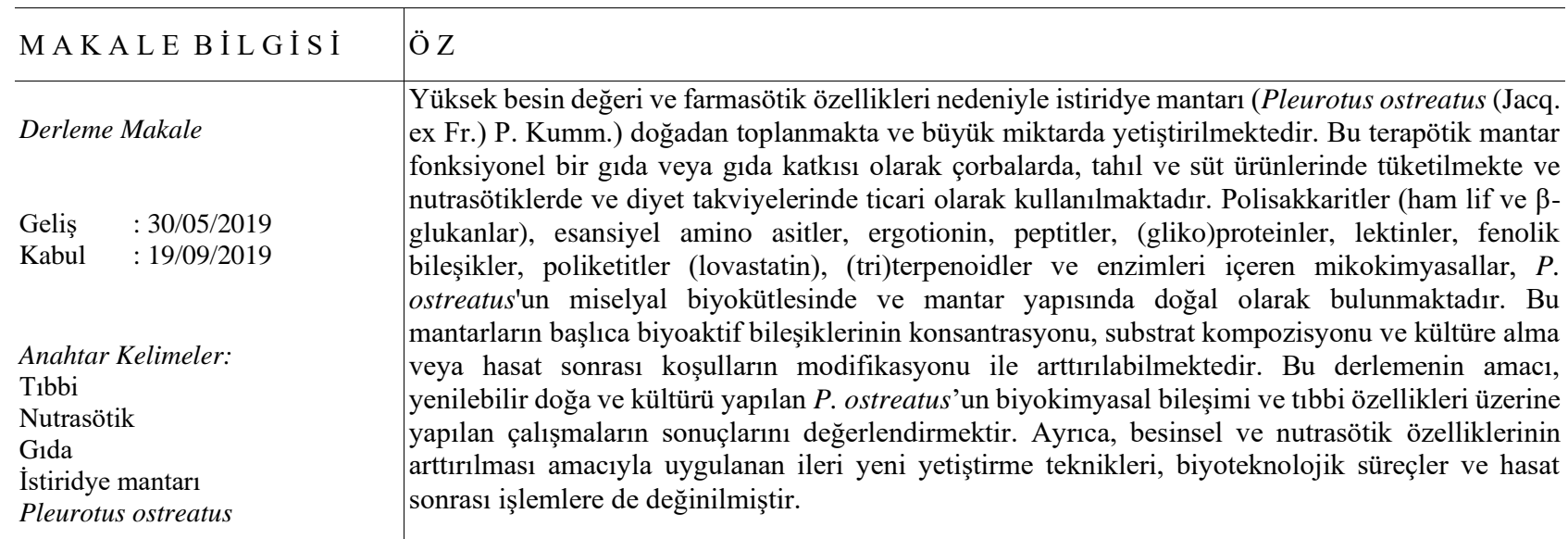




\section{Introduction}

Pleurotus species are exclusive wood decomposers. They grow on a wide array of forest and agricultural wastes (Adebayo and Oloke, 2017) in tropical and subtropical areas and are easily cultivated (Chang and Miles, 1989; Kues and Liu, 2000; Kibar and Pekşen, 2008). They colonize on almost all hardwoods such as Abies, Acacia, Acer, Alnus, Betula, Carpinus, Carya, Castanea, Laurocersus, Liquidambar, Liriodendron, Lupinus, Magnolia, Malus, Morus, Nyssa, Ostrya, Pandanus, Picea, Pistacia, Populus, Pseudotsuga, Quercus, Salix, Tilia, Ulmus, and Wisteria (Anonymous, 2013) and on wood byproducts (sawdust, paper, pulp sludge), all the cereal straws, corn and corn cobs, sugar cane bagasse, coffee residues (coffee grounds, hulls, stalks, and leaves), banana fronds, cottonseed hulls, agave waste, soy pulp, and other materials (Ragunathan and Swaminathan, 2003; Sanchez, 2010; Adebayo and Oloke, 2017). Mushrooms of Pleurotus spp. (under the class Basidiomycetes) are edible and among the most popular mushrooms worldwide. Pleurotus spp. include $P$. citrinopileatus Singer, $P$. cystidiosus O.K. Mill., P. eryngii (DC.) Quél., P. flabellatus Sacc., P. florida Singer, P. geesteranus Singer, P. ostreatus (Jacq.) P. Kumm., P. pulmonarius (Fr.) Quél., $P$. sajor-caju (Fr.) Singer, P. sapidus Quél., P. tuberregium (Fr.) Singer, P. ulmarius (Bull.) P. Kumm., and about 40 different species. They are prolific producers of novel "mycochemicals" (Deepalakshmi and Mirunalini, 2014) and some of them are of a special consideration due to their high nutritional value and medicinal importance (Chang and Miles, 1989; Kues and Liu, 2000; Khan and Tania, 2012; Gomes-Correa et al., 2016). Pleurotus species are recognized as dual functional mushrooms as both food and medicine. They include high quality of proteins, vitamins and minerals. Medicinally, they are recommended to obese and diabetes patients because of their low caloric value and very low sugar content without starch (Chang and Buswell, 2003). Furthermore, no case reports about allergy symptoms have been found in the literature (Anonymous, 2013).

Among species of this genus, $P$. ostreatus is the most popularly consumed one due to its taste, flavor, high nutritional value, and medicinal properties. It commonly exists in the mycobiota of Turkey as well as different locations of the world (Sesli and Denchev, 2014; Alkan et al., 2016; Doğan and Kurt, 2016; Akata and Uzun, 2017; Akata et al., 2019). Within the ethnomycological perspective, the edible wild Pleurotus species including $P$. ostreatus known as "Kavak mantar1 (Poplar mushroom)" are traditionally collected from the forests during the rainy season from March to November and sold in the local markets by the villagers (Kibar and Pekşen, 2008; Alkan et al., 2016; Doğan and Kurt, 2016; Pekşen et al., 2016; Pekşen and Kaplan, 2017). The Pleurotus species have many advantages as a cultivated mushroom: rapid mycelia growth, high ability for saprophytic colonization, simple and inexpensive cultivation techniques and several kinds of species, which are available for cultivation under different climatic conditions (Kibar and Pekşen, 2008). In recent years, $P$. ostreatus is commercially cultivated because of its rich mineral contents and medicinal properties, short life cycle, reproducibility in the recycling of certain agricultural and industrial wastes, and low demand on resources and technology (Yildiz et al., 2002). Pleurotus is the second most important cultivated mushroom genus for food purposes throughout the world and Turkey with a share of $27 \%$ and $10 \%$, respectively (Royse, 2014; Eren and Pekşen, 2016). In addition, Pleurotus mushrooms are preferred because they are suitable for the organic production (Aksu and Uygur, 2005). P. ostreatus was reported to have a unique flavor and aromatic properties and considered to be rich in protein, fiber, carbohydrates, vitamins, and minerals. Among the volatile compounds that constitute edible mushroom flavor, 1-octen-3-ol is considered to be the major contributor. $P$. ostreatus is an excellent source of crude fiber (11.8\%) and $\beta$-glucans $(29.5 \%)$ and its Amino Acid Score (AAS) meets the nutritional requirements of all essential amino acids for adults (Carrasco-González et al., 2017). $P$. ostreatus is rich in numerous nutritional compounds and various active ingredients, therefore, it has been reported to possess hematological, hypocholesterolic, antidiabetic, antibacterial, anticholesterolemic, antibiotic, antiarthritic, antioxidant, anticancer, antiviral functions, and immunomodulation activities (Cohen et al., 2002; Deepalakshmi and Mirunalini, 2014; Adebayo and Oloke, 2017). A therapeutic effect can be achieved by consuming fresh oyster mushroom fruiting bodies, foodstuffs containing dried oyster mushrooms or supplements with such content (Golak-Siwulska et al., 2018). Pleurotus species have a great potential to produce novel value-added products (Wakchaure et al., 2010). The incorporation of dried cultivated $P$. ostreatus into processed foods such as wheat bread (Ndung'u et al., 2015; Oyetayo and Oyedeji, 2018), yoghurt (Pelaes et al., 2015), meatball (Süfer et al., 2016), and chips (Doğan et al., 2017) as an additive has been reported to enhance sensory, nutritional, nutraceutical or functional characteristics, in addition, the bioactive compound bioavailability of the products enriched with $P$. ostreatus was studied (Regula et al., 2016). In recent years, some dietary supplements derived from $P$. ostreatus have also been produced and these are commercially available in the market (Reis et al., 2017; Bulam et al., 2018; Üstün et al., 2018). Hence, besides conventional extraction methods, advanced green technologies have also been used to produce higher recoveries of diverse $P$. ostreatus bioactive compounds such as phenolic compounds, ergothioneine, $\beta$-glucans, and other polysaccharides, recently (Morales et al., 2018). In addition, some other advanced technologies have been applied to prevent the effects of oxidation and microbial growth on these compounds and increase their capacities in the treatment of some serial diseases as cancer (Mahmoud et al., 2015; 2016). There is no clear suggestion for the daily dose of $P$. ostreatus intake (Khan and Tania, 2012), however there have been some clinical studies on children, adults, and athletes about pharmacological benefits and safe doses of $P$. ostreatus derived products and dietary supplements (Khan and Tania, 2012; Jesenak et al., 2017; Rathore et al., 2017). Besides the aim of consumption as food and dietary supplement, cultivation of Pleurotus spp. was reported to provide an eco friendly method for effective disposal of various agro-wastes used as substrate in mushroom 
cultivation (Ragunathan and Swaminathan 2003). Furthermore, these mushrooms have been used for the products in terms of medicinal (Kues and Liu, 2000; Golak-Siwulska et al., 2018), cosmetic and cosmeceutical (Taofiq et al., 2016; Wu et al., 2016) purposes, and the production of ligninolytic enzymes that can be used for various biotechnological and environmental applications such as using in bioremediation of resistant pollutants and the bioconversion of agricultural wastes into valuable products for animal feed (Cohen et al., 2002; Akinfemi et al., 2010). In addition, nano polysaccharides ( $\beta$-glucan) extracted from $P$. ostreatus were expected to have a great potential for use in industrial scale as an emulsifier and a flocculating agent (Mahmoud et al., 2015). Due to growing importance and demand of $P$. ostreatus today, in this review, it has been aimed to review actual information about the studies on the nutritional and medicinal properties of edible wild and cultured $P$. ostreatus in addition to novel cultivation techniques, biotechnological processes, and postharvest treatments to increase its nutritional and nutraceutical values.

\section{Nutritional and Medicinal Values of Wild P. ostreatus}

When wild $P$. ostreatus was evaluated in terms of nutrition, Akyüz and Kırbağ (2010) determined dry matter, moisture, crude ash, crude protein, crude fat, crude cellulose, organic matter, and nitrogen-free extract as 89.7, $10.3,12.7-13.7,27.8-32.8,0.9-1.3,10.4-16.2,76.0$ and 26.7-36.8\% dw, respectively. Johnsy et al. (2011) detected dry matter $(4.87 \%)$, carbohydrates $(43.40 \%)$, lipids $(2.47 \%)$, protein $(37.63 \%)$, fibre $(4.20 \%)$, and ash $(10.17 \%)$. In another study; moisture, protein, fat, carbohydrate, and ash were reported as 89.69, 16.96, 3.21, 62.27 and $7.25 \%$, respectively (Akata et al. 2012). Turfan et al. (2018) found total soluble protein, total free amino acid, total soluble carbohydrates, glucose, fructose, and sucrose as 33.57, 2.83, 59.89, 8.96, 0.33 and $10.90 \mathrm{mg} / \mathrm{g}$ in the wild $P$. ostreatus samples, respectively. Sevindik et al. (2016) detected $\mathrm{Na}, \mathrm{Zn}, \mathrm{Mg}$, and Fe contents as 125.5, $45.9,161.9$ and $57.1 \mathrm{mg} / \mathrm{kg}$, respectively. Keleş et al. (2017) determined $\mathrm{K}, \mathrm{Mg}, \mathrm{Ca}, \mathrm{Mn}$, and $\mathrm{Fe}$ as 5523, 901.7, $454.6,7.7$ and $104.5 \mathrm{mg} / \mathrm{kg} \mathrm{dw}$, respectively. Turfan et al. (2018) reported Se content of wild P. ostreatus as 2.69 $\mathrm{mg} / \mathrm{kg}$. In another study, total protein, vitamin A, vitamin $\mathrm{E}$, and vitamin C were found as $36.25 \%, 9.62 \mu \mathrm{g} / \mathrm{g}, 998.24$ $\mu \mathrm{g} / \mathrm{g}$ and 1,481.25 $\mu \mathrm{g} / \mathrm{g}$, respectively (Bengu et al., 2019).

From medicinal point of view, Keleş et al. (2011) detected the antioxidant properties of $P$. ostreatus extracts as total phenolic $(2686.67 \mathrm{mg} / \mathrm{kg})$, FRAP (2385.71 $\mu \mathrm{mol} / \mathrm{g}), \mathrm{DPPH}(86.35 \%$ at $25 \mathrm{mg} / \mathrm{mL})$, and $\mathrm{EC}_{50}(11.07$ $\mathrm{mg} / \mathrm{mL}$ ). In Akata et al. (2012) study, P. ostreatus showed the most potent free radical scavenging antioxidant activity $(96.16 \%)$ at $2.72 \mathrm{mg} / \mathrm{mL}$ of methanol extract concentration. Vishwakarma et al. (2017) reported the highest antioxidant activity of $P$. ostreatus in all studied protocols as DPPH $(0.19 \mathrm{mg} / \mathrm{mL}), \beta$-carotene bleaching assay $(0.36 \mathrm{mg} / \mathrm{mL})$, and $\mathrm{H}_{2} \mathrm{O}_{2}$ scavenging assay $(0.82$ $\mathrm{mg} / \mathrm{mL}$ ) in comparison to $P$. cystidiosus, $P$. flabellatus, and $P$. florida. In another study, total phenolics and total flavonoids were indicated as 122.68 and $19.81 \mathrm{mg} / \mathrm{g}$, respectively (Turfan et al., 2018). Bozdoğan et al. (2018) determined total phenolic, flavonoid, and $\beta$-carotene contents of the $\mathrm{MeOH}$ extracts of $P$. ostreatus as 15.66 $\mathrm{mg} / \mathrm{kg}, 0.16 \mathrm{mg} / \mathrm{kg}, 0.02 \mathrm{mg} / 100 \mathrm{~mL}$, respectively. In addition, at $5 \mathrm{mg} / \mathrm{mL}$, DPPH, RP, $\mathrm{H}_{2} \mathrm{O}_{2}$, NO and FRAP activities of $P$. ostreatus were found as $17.42 \%, 0,530$ Abs., $73.77 \%, 33.64 \%, 0.28 \mathrm{mmol} \mathrm{Fe}{ }^{2+} / \mathrm{L}$, respectively. Sevindik et al. (2018) detected total antioxidant status (TAS), total oxidant status (TOS), and oxidative stress index (OSI) of edible wild P. ostreatus as $2.023 \mathrm{mmol} / \mathrm{L}$, $7.048 \mu \mathrm{mol} / \mathrm{L}$ and 0.351 , respectively.

\section{Nutritional and Medicinal Values of Cultivated $P$. ostreatus}

Commercially cultivated mushroom has similar contents of nutritional components compared with wild type mushroom. However, there are some qualitative and quantitative differences in the chemical composition of $P$. ostreatus products depending on the strain, origin, extraction process, and cultivation conditions (Wang et al., 2001; Akyüz and Kırbağ, 2010). Cultivated P. ostreatus was characterized by a medium calorific value of $151 \mathrm{~J}$ (Manzi et al., 2001) and metabolizable energy content of $242.6 \mathrm{kcal}$ (Khan et al., 2008) in $100 \mathrm{~g}$. Moisture content was detected as $86.5 \%$ and protein, lipid, carbohydrate, fiber, and ash were determined as 23.5, 2.6, 39.4, 27.0 and $7.4 \mathrm{~g} / 100 \mathrm{~g}$ of dried sample, respectively (Khan et al., 2008). Akyüz and Kirbağ (2010) reported dry matter, moisture, crude ash, crude protein, crude fat, crude cellulose, organic matter, and nitrogen-free extract as 90.0, 10.0, 6.0, 41.6, 0.5, 14.3, 84.0 and $29.6 \% \mathrm{dw}$, respectively. Oyetayo and Ariyo (2013) determined amino acid composition as alanine $(3.75 \mathrm{~g} / 100 \mathrm{~g})$, arginine $(6.30 \mathrm{~g} / 100$ $\mathrm{g})$, aspartic acid (4.30 g/100 g), glutamic acid (10.20 g/100 $\mathrm{g})$, glycine $(1.65 \mathrm{~g} / 100 \mathrm{~g})$, histidine $(1.10 \mathrm{~g} / 100 \mathrm{~g})$, isoleucine $(1.26 \mathrm{~g} / 100 \mathrm{~g})$, leucine $(2.31 \mathrm{~g} / 100 \mathrm{~g})$, lysine $(1.50 \mathrm{~g} / 100 \mathrm{~g})$, methionine $(0.53 \mathrm{~g} / 100 \mathrm{~g})$, and cysteine (0.53 g/100 g). Korkmaz and Kirbağ (2014) reported palmitic acid, stearic acid, linoleic acid, oleic acid and docosadyenoic acid on different compost mediums as $22.64-33.06 \%, \quad 14.08-15.80 \%, \quad 36.69-41.98 \%$, $18.83-$ $53.50 \%$ and $9.79-15.54 \%$, respectively. In another study, total SFA, MUFA, and PUFA were detected as 17.0, 13.6 and $69.4 \%$ of total FA, respectively (Reis et al., 2012). Yang et al. (2001) found total soluble sugars (arabitol, glucose, mannitol, myo-inositol, trehalose), total free amino acids, and total $5^{\prime}$-nucleotids as 4.1, 18.2 and 15.8 $\mathrm{mg} / \mathrm{g} \mathrm{dw}$, respectively. Turfan et al. (2018) determined total soluble protein, total free amino acid, total soluble carbohydrates, glucose, fructose, and sucrose as 75.73108.66, 4.70-7.43, 222.61-279.32, 33.36-41.90, 0.05-4.71 and $2.85-12.17 \mathrm{mg} / \mathrm{g}$, respectively. Teichmann et al. (2007) reported ergosterol, total sterol, and vitamin $\mathrm{D}_{2}$ values of dark cultivated $P$. ostreatus as $60.7,72.4 \mathrm{mg} / 100 \mathrm{~g}$ fw and $0.7 \mu \mathrm{g} / 100 \mathrm{~g}$ fw, respectively. Bengu et al. (2019) detected total protein, vitamin $\mathrm{A}$, vitamin $\mathrm{E}$, and vitamin $\mathrm{C}$ as $23.18 \%, 66.86 \mu \mathrm{g} / \mathrm{g}, 654.16 \mu \mathrm{g} / \mathrm{g}$ and $334.36 \mu \mathrm{g} / \mathrm{g}$, respectively. Çağlarırmak (2007) reported texture, moisture, ash, and protein as $0.33 \mathrm{~kg} / \mathrm{mm}^{2}, 92.63,0.63$ and $0.92 \% \mathrm{wb}$, respectively. In this study, folic acid, vitamin C, thiamin, riboflavin, and niacin were also determined as $9.08 \mu \mathrm{g} / 100 \mathrm{~g}, 3.38,0.15,0.21$ and $4.44 \mathrm{mg} / 100 \mathrm{~g} \mathrm{wb}$, respectively. Main volatile compounds detected by GS-MS library estimation were nonadecanoic acid (26.28\%) and 
9,12-Octadecadien-1-ol (24.64\%) in the same study. Reis et al. (2012) determined $\alpha$-tocopherol, $\gamma$-tocopherol, and $\delta$ tocopherol as $0.59,1.49$ and $1.64 \mu \mathrm{g} / 100 \mathrm{~g}$ fw where $\beta$ tocopherol was not detected. In addition, $\mathrm{Zn}, \mathrm{Fe}, \mathrm{P}, \mathrm{Ca}, \mathrm{Mg}$, $\mathrm{K}$, and $\mathrm{Na}$ amounts were reported as $11.18,14.80$, 998.47, $81.16,221.9,2225.00$ and $773.67 \mathrm{mg} / \mathrm{kg} \mathrm{wb}$, respectively. Sevindik et al. (2016) found $\mathrm{Na}, \mathrm{Zn}, \mathrm{Mg}$, and Fe contents as $267.9,134.9,166.6$ and $451.3 \mathrm{mg} / \mathrm{kg}$, respectively. Khan and Tania (2012) informed Se content of P. ostreatus as $0.011 \mathrm{mg} / 100 \mathrm{~g}$ dried mushrooms. Synytsya et al. (2008) detected that the fruiting bodies contained small amounts of $\alpha$-glucans: $3.4-7.9 \%$ in the caps and $3.0-7.6 \%$ in the stems, respectively. The contents of $\beta$-glucans were found as $27.4-39.2 \%$ in the caps and $35.5-50.0 \%$ in the stems of $P$. ostreatus. In the same study, the highest TDF level $(64.8 \%)$ was observed in the stems of strain 77 , while the lowest TDF level (34.5\%) was in the caps of strain L22 $P$. ostreatus related to dry matter. Manzi et al. (2001) determined chitin and $\beta$-glucan content of raw commercial P. ostreatus samples as $0.32 \mathrm{~g} / 100 \mathrm{~g}$ and $139.2 \mathrm{mg} / 100 \mathrm{~g}$ edible weight $(\mathrm{dm})$ and its dietary fibre values as 4.10 (TDF), 3.67 (IDF) and 0.43 (SDF) g/100 g edible weight (dm), respectively. Honda et al. (1999) found an association between high fiber diets and a lower incidence of cardiovascular diseases and large bowel cancers. Synytsya et al. (2009) reported that $P$. ostreatus contained branched $\beta$-1,3-1,6-glucan and linear $\alpha$-1,3-glucan as the major components of cell walls. In addition, potential prebiotic activity of the extracts was also detected by using diverse probiotic strains. Sari et al. (2017) also detected $\alpha$ glucans and $\beta$-glucans as 1.405 and $24.231 \mathrm{~g} / 100 \mathrm{~g} \mathrm{dm}$ in commercially cultivated $P$. ostreatus samples, respectively. Chen et al. (2012) determined the highest lovastatin, GABA and ergothioneine contents of $P$. ostreatus fruiting bodies from Japan, Korea and Taiwan as $606.5,23.6$ and $1829.4 \mathrm{mg} / \mathrm{kg} \mathrm{dw}$, respectively. In another study, caffeic acid, gallic acid, p-hydroxybenzoic acid, myricetin, and ergothioneine contents of $P$. ostreatus were detected as 7.80, 13.0, 1.27, $1.67 \mu \mathrm{g} / \mathrm{g}$ and $3.78 \mathrm{mg} / \mathrm{g}$ in $\mathrm{dw}$ (Woldegiorgis et al., 2014). Abidin et al. (2017) indicated that $P$. ostreatus exhibited the best candidate for prevention and treatment of atherosclerosis via hypocholesterolemia due to the fact that it has been proven to contain a large amount of anti-atherosclerotic agents such as ergothioneine, lovastatin, and chrysin.

Kalyoncu et al. (2010) found that the most active species were $P$. ostreatus and $M$. giganteus which showed broad spectrum antimicrobial activity against Gram (+) and Gram (-) bacteria in the grown mycelia extracts. Besides, scavenging capacity of the mycelial extracts (DPPH$6.11 \%)$ and equivalent inhibition values of TOC $(2.37$ $\mu \mathrm{g} / \mathrm{ml}$ ) were detected for $P$. ostreatus in the same study. Woldegiorgis et al. (2014) determined total phenolics, total flavonoids, antioxidant activity in DPPH scavenging, reducing power, and chelating effect assays as $14.6 \mathrm{mg}$ $\mathrm{GAE} / \mathrm{g}, 1.97 \mathrm{mg} \mathrm{CE} / \mathrm{g}, 1.4,3.6$ and $0.035 \mathrm{EC}_{50}$, respectively. Yilmaz et al. (2016) reported the total phenolic content as $151.4 \mathrm{mg}$ GAE/100 $\mathrm{g}$ and the antioxidant activity as $2508 \mu \mathrm{mol} \mathrm{FeSO}_{4} .7 \mathrm{H}_{2} \mathrm{O} / \mathrm{g}$. In addition, methanolic extracts of $P$. ostreatus showed inhibitory effect against Klebsiella pneumonia and Acinetobacter haemolyticus bacteria. According to Y1lmaz et al. (2017), total phenolic, condensed tannin, FRAP, and
DPPH values of mushroom samples grown on different substrates ranged from 1.07 to $2.67 \mathrm{mg} \mathrm{GAE} / \mathrm{g}, 0.42$ to $1.01 \mathrm{CE} \mathrm{mg} / \mathrm{g}, 4.09$ to $12.33 \mu \mathrm{mol} \mathrm{FeSO}_{4} .7 \mathrm{H}_{2} \mathrm{O} / \mathrm{g}$ and 4.94 to $15.47 \mathrm{mg} / \mathrm{mL}$, respectively. Adebayo et al. (2018) found that $\beta$-carotene-linoleic acid and ORAC assays showed high antioxidant activity, particularly in $P$. ostreatus. Sevindik et al. (2018) detected total antioxidant status (TAS), total oxidant status (TOS), and oxidative stress index (OSI) of cultivated P. ostreatus as $1.153 \mathrm{mmol} / \mathrm{L}$, $1.071 \mu \mathrm{mol} / \mathrm{L}$ and 0.092 , respectively. Turfan et al. (2018) determined total phenolics and total flavonoids as 53.68119.68 and $8.55-11.21 \mathrm{mg} / \mathrm{g}$, respectively. Özdal et al. (2019) detected the highest total phenolic content in $P$. ostreatus hot water extract $(9.14 \mathrm{mg} / \mathrm{g}$ dry weight of extract). In addition, mycelia extracts from Pleurotus species showed antibacterial activity against Gram (-) and Gram (+) plant and human pathogenic bacteria. Since the extract from $P$. ostreatus showed antioxidant and antibacterial properties, it could be used in the formulation of nutraceuticals. Moreover, Sevindik et al. (2016) reported that the ethanolic extracts of the wild and cultured forms of $P$. ostreatus were found to have low antimicrobial activity being more effective on fungal strains, Candida albicans and $C$. tropicalis than bacterial strains.

There are various in vivo, in vitro and clinical study results reporting the medicinal and therapeutic properties of $P$. ostreatus (Khan and Tania, 2012; Patel et al., 2012; Deepalakshmi and Mirunalini, 2014; Correa et al., 2016; Adebayo and Oloke, 2017; Carrasco-González et al., 2017; Piska et al., 2017; Rathore et al., 2017; Golak-Siwulska 2018; Kumar, 2019). Furthermore, the extracts or powder of fruiting bodies or mycelia of $P$. ostreatus have been reported to have anticancer, antitumor, antiviral, antihypercholesterolemic, antihypertensive, antidiabetic, antiobesity, hepatoprotective, hypoglysemic, immunomodulatory, antiaging, antiallergic, antiarthritic, anti-HIV, antineoplastic, antimutagenic, antiinflammatory, anti-atherogenic, anti-atopic dermatitis, antiatherosclerotic, antimicrobial, and antioxidant activities and therapeutic properties depending on high and low molecular weight bioactive compounds such as $\beta$-glucans, $\alpha$-glucan, proteins, polysaccharides, proteoglycans, heteroglycan, lectin, lovastatin, chrysin, ergosterol, ergothioneine, pleuran, terpenes, fatty acid esters, and polyphenols.

\section{Cultivation Techniques for Increasing Nutraceutical Value of $P$. ostreatus}

The Pleurotus fruiting bodies dramatically respond to the chemical composition of the substrate (CarrascoGonzález et al., 2017). Higher protein values were obtained in P. ostreatus depending on different types of substrate, treatment, mycelium, and the weight of the bag used (Pardo et al., 2005; 2007; 2008). Tropical woody substrates of Pycnanthus ongoleubis used in cultivation of $P$. ostreatus caused higher mineral, protein, carbohydrate, fat, and dietary fiber contents in addition to all amino acids except phenlyalanine in the fruiting bodies (Oyetayo and Ariyo, 2013). Nieto and Chegwin (2013) determined high content of triterpenoids after the cultivation in the mixtures of cereal straws. It has been reported that Agave sisalana saline solid waste produced $P$. ostreatus fruiting bodies with higher antioxidant activity (Muthangya et al., 2014). 
Kırbağ and Korkmaz (2014) determined the second highest protein content in $P$. ostreatus $(36.4 \%)$ cultured in growing medium supplemented with wheat stalk. On the other hand, Picornell-Buendía et al. (2016) reported that substrates supplemented with wheat bran and the commercial supplement (Calprozime $\left.{ }^{\circledR}\right)$ have shown good agronomic performance for $P$. ostreatus and yielded higher protein and ash content.

Mushroom supplementation is an agronomic process which consists of the application of nutritional amendments to the substrates employed for the mushroom cultivation (Carrasco et al., 2018). Besides using substrates with high contents of bioactive compounds, mineral supplementation has also profound effects on Pleurotus nutraceutical composition (Carrasco-González et al., 2017). The cultivation on Se-enriched substrates produced fruiting body with increased phenolic content and antioxidant (Gasecka et al., 2015). Culture of P. ostreatus on $\mathrm{FeSO}_{4}(0.8 \mathrm{mg} / \mathrm{kg})$ and $\mathrm{ZnCO}_{3}(2.13 \mathrm{mg} / \mathrm{kg})$ enriched substrates produced fruiting body with higher phenolic content but lower antioxidant, whereas the addition of $\mathrm{Li}$ reduced phenolic content (Fontes-Vieira et al., 2013). $P$. ostreatus fruiting body cultivated on Se-enriched substrate (0.5 mM) bioaccumulated $63 \mu \mathrm{g} / \mathrm{g}$ Se (Niedzielski et al., 2015). In another study, the highest level of Se absorption was obtained by adding $51 \mathrm{mg} / \mathrm{kg}$ of $\mathrm{Na}_{2} \mathrm{SeO}_{3}$ into the coffee husk substrate and Se bioaccumulation was 58-858 $\mu \mathrm{g} \mathrm{Se} / \mathrm{g} \mathrm{dw}$ in the fruiting bodies (Da Silva et al., 2012). Moreover, Da Silva et al. (2010) showed that Seenriched mushrooms can be considered as an alternative Se-food source for humans, due to their high bioavailability in vivo. Milovanovic et al. (2014) studied Se supplementation as $\mathrm{Na}_{2} \mathrm{SeO}_{3}$ at concentrations of 5-20 $\mu \mathrm{g} / \mathrm{mL}$ into the synthetic medium. Se bioaccumulation was 251-939 $\mu \mathrm{g} \mathrm{Se/g} \mathrm{dw} \mathrm{in} \mathrm{the} \mathrm{mycelia.} \mathrm{Pleurotus} \mathrm{species}$ cultivation with mineral-enriched substrates is an economic and fast strategy to enhance the nutritional and medicinal properties of fruiting bodies (Carrasco-González et al., 2017).

\section{Post-harvest Treatments for Increasing Nutraceutical Value of $P$. ostreatus}

In the past years, diverse post-harvest treatments such as cold storage, modified atmosphere packaging (MAP), gamma and electron beam irradiation, and coating have been investigated in an effort to discover new alternatives for prolongation the shelf life of various mushrooms (Correa et al., 2016). Jaworska et al. (2011) determined that with the exception of samples blanched in water, frozen mushrooms had higher levels of all the investigated amino acids than canned mushrooms. Jaworska et al. (2015) prepared $P$. ostreatus mushrooms (raw or blanched) for consumption by braising with $10 \%$ rapeseed oil. They reported higher contents of crude protein, crude fat, total ash, energy, total tocopherols $(\alpha, \gamma, \delta)$, and vitamin $\mathrm{E}$ activity on the contrary decreases in B group vitamins, total phenols, total flavonoids, vitamin $\mathrm{C}$, carotenoids, and antioxidant activity after preparation and storage. In addition, blanched mushrooms resulted in lower levels of nutraceuticals and lower values of antioxidant activity than raw mushrooms prepared for consumption. Kortei et al. (2014) studied gamma irradiation between 0.5-2.0 kGy doses and reported an increase in phenolic, flavonoid, and antioxidant content between 0.5 and $1.0 \mathrm{kGy}$ doses. Huang et al. (2015) studied the effect of UV-B light irradiation on the amount of vitamin $\mathrm{D}_{2}$ content of edible fruiting bodies and mycelia of five Pleurotus spp., and their antioxidant properties. The vitamin $\mathrm{D}_{2}$ content of irradiated fruiting bodies significantly increased from 0-3.93 to 15.06-208.65 $\mu \mathrm{g} / \mathrm{g}$, vitamin $\mathrm{D}_{2}$ content in irradiated mycelia of $P$. citrinopileatus, $P$. ostreatus, and $P$. salmoneostramineus mushrooms increased from $0.28-5.93$ to $66.03-81.71 \mu \mathrm{g} / \mathrm{g}$, respectively. The three irradiated mycelium polysaccharide contents decreased in a range from 1.3 to $24.6 \%$. Despite the fact that UV-B irradiation affected the content of ergothioneine, flavonoids and total phenols, the irradiated samples still contained a sufficient amount of these antioxidant components. Tolera and Abera (2017) studied the effects of different levels of osmotic pretreatments prior to drying and different drying methods on nutritional quality of dried mushroom slices and reported that salt concentration increased from 0 to 5 and $10 \%$, the protein content reduced from 26.78 to 25.99 and $24.95 \% \mathrm{db}$, the fat reduced from 2.42 to 2.19 and $1.94 \% \mathrm{db}$ and fiber from 12.82 to 9.41 and $9.01 \% \mathrm{db}$, respectively. Contrarily, the ash increased from 9.75 to 10.77 and $12.20 \% \mathrm{db}$ and the carbohydrate from 38.16 to 43.08 and $45.18 \% \mathrm{db}$, respectively. Bakır et al. (2018) investigated the antioxidant capacity of $P$. ostreatus stored in five different temperature environments. The $\mathrm{IC}_{50}$ values of $P$. ostreatus for four different concentrations were found as inh $_{+20^{\circ} \mathrm{C}}>$ inh $_{+4^{\circ} \mathrm{C}}>$ inh $_{-10^{\circ} \mathrm{C}}>$ inh $_{-20^{\circ} \mathrm{C}}>$ inh $_{-40^{\circ} \mathrm{C}}$, respectively. As a conclusion, the temperature factor of oyster mushroom in the range of -40 to $+20{ }^{\circ} \mathrm{C}$ storage conditions was directly proportional to the change of antioxidant properties.

\section{Conclusion}

P. ostreatus is an edible mushroom with high nutritional and biomedical importance, since it contains a number of bioactive components that also develop its large number of therapeutic functions. It has the potentiality to control many human diseases so the fruiting bodies, mycelia and extracts or concentrates of $P$. ostreatus have been considered as functional food and nutraceutical. Since, most of the therapeutic effects of $P$. ostreatus are based on in vivo and in vitro studies, more clinical trials are needed to fully realize its potentials. In addition, $P$. ostreatus requires shorter growth time than the other edible mushrooms and a high percentage of the substrate is converted to fruiting bodies which increases the profitability as compared to other mushrooms. Therefore, $P$. ostreatus is an excellent choice for mushroom cultivation with high yield and quality. For this reason, new standardized strategies must be developed to increase the bioavailability, nutritional, and nutraceutical value of $P$. ostreatus during cultivation and after harvest.

\section{References}

Abidin MHZ, Abdullah N, Abidin NZ. 2017. Therapeutic properties of Pleurotus species (oyster mushrooms) for atherosclerosis: A review. Int J of Food Proper, 20(6): 12511261. 
Adebayo EA, Oloke JK. 2017. Oyster mushroom (Pleurotus species): A natural functional food. J Microbiol Biotech Food Sci, 7(3): 254-264.

Adebayo EA, Martinez-Carrera D, Morales P, Sobal M, Escudero H, Meneses ME, Avila-Nava A, Castillo I, Bonilla M. 2018. Comparative study of antioxidant and antibacterial properties of the edible mushrooms Pleurotus levis, P. ostreatus, $P$. pulmonarius and $P$. tuber-regium. Int J Food Sci Technol, pp. $1-15$.

Akata I, Ergönül B, Kalyoncu F. 2012. Chemical compositions and antioxidant activities of 16 wild edible mushroom species grown in Anatolia. Int J Pharmacol, 8: 134-138.

Akata I, Uzun Y. 2017. Macrofungi determined in Uzungöl nature park (Trabzon). Trakya Univ J Nat Sci, 18(1): 15-24.

Akata I, Altuntaş D, Kabaktepe Ş. 2019. Fungi determined in Ankara University Tandoğan campus area (Ankara-Turkey). Trakya Univ J Nat Sci, 20(1): 47-55.

Akinfemi A, Adu OA, Doherty F. 2010. Conversion of sorghum stover into animal feed with white-rot fungi Pleurotus ostreatus and Pleurouts pulmonarius. Afr J Biotechnol, 9(11): 1706-1712.

Aksu Ş, Uygur AM. 2005. Bazı kayın mantarı (Pleurotus spp.) türlerinin organik olarak üretimi üzerinde araştırmalar. Anadolu, J of AARI, 15(2): 1-26.

Akyüz M, Kırbağ S. 2010. Nutritive value of wild edible and cultured mushrooms. Turk J Biol, 34: 97-102.

Alkan S, Kaşık G, Öztürk C, Aktaş S. 2016. Çorum ilinin yenir özellikteki makromantarları. Turkish J Agr - Food Sci and Technol, 4(3): 131-138.

Anonymous. 2013. Consensus document on compositional considerations for new varieties of oyster mushroom [Pleurotus ostreatus]: Key Food and Feed Nutrients, Antinutrients and Toxicants. OECD Environment, Health and Safety Publications, Series on the Safety of Novel Foods and Feeds, No. 26, 42 p.

Bakır T, Karadeniz M, Unal S. 2018. Investigation of antioxidant activities of Pleurotus ostreatus stored at different temperatures. Food Sci Nutr, 6: 1040-1044.

Bengu AS, Çinar Yilmaz H, Turkekul İ, Ișik H. 2019. The levels of minerals and vitamins in some wild and cultured mushroom species from Turkey. J Pharm Pharmacol, 7: 207-211.

Bozdoğan A, Ulukanlı Z, Bozok F, Eker T, Doğan HH, Büyükalaca S. 2018. Antioxidant potential of Lactarius deliciosus and Pleurotus ostreatus from Amanos Mountains. Adv Life Sci, 5(3): 113-120.

Bulam S, Üstün NŞ, Pekşen A. 2018. $\beta$-glucans: An important bioactive molecule of edible and medicinal mushrooms. In: Türkmen, A. (ed.). 1. International Technology Sciences and Design Symposium (ITESDES) Proceeding Book. Giresun, Turkey. Giresun University. 27-29 June 2018. pp: 1242-1258.

Carrasco J, Zied DC, Pardo JE, Preston GM, Pardo-Giménez A. 2018. Supplementation in mushroom crops and its impact on yield and quality. AMB Expr, 8: 146.

Carrasco-González JA, Serna-Saldívar SO, Gutiérrez-Uribe JA. 2017. Nutritional composition and nutraceutical properties of the Pleurotus fruiting bodies: Potential use as food ingredient. J Food Compost Anal, 58: 69-81.

Chang ST, Miles PG. 1989. Edible Mushrooms and Their Cultivation. CRC Press: Boca Raton, FL, pp: 1-38. ISBN13: 9780849367588.

Chang ST, Buswell JA. 2003. Medicinal mushrooms-as prominent source of nutriceuticals for the 21 st century. Curr Topics Nutraceut Res, 1: 257-280.

Chen SY, Ho KJ, Hsieh YJ, Wang LT, Mau JL. 2012. Contents of lovastatin, $\gamma$-aminobutyric acid and ergothioneine in mushroom fruiting bodies and mycelia. LWT Food Sci Technol, 47: 274-278.

Cohen R, Persky L, Hadar Y. 2002. Biotechnological applications and potential of wood-degrading mushrooms of the genus Pleurotus. Appl Microbiol Biotechnol, 58: 582-594.
Correa RCG, Brugnari T, Bracht A, Peralta RM, Ferreira ICFR. 2016. Biotechnological, nutritional and therapeutic uses of Pleurotus spp. (oyster mushroom) related with its chemical composition: A review on the past decade findings. Trends Food Sci Technol, 50: 103-117.

Çağlarırmak N. 2007. The nutrients of exotic mushrooms (Lentinula edodes and Pleurotus species) and an estimated approach to the volatile compounds. Food Chem, 105: 11881194.

Da Silva MCS, Naozuka J, Oliveira PV, Vanetti MCD, Bazzolli DMS, Costa NMB, Kasuya MCM. 2010. In vivo bioavailability of selenium in enriched Pleurotus ostreatus mushrooms. Metallomics, 2: 162-166.

Da Silva MCS, Naozuka J, da Luz JMR, de Assunção LS, Oliveira PV, Vanetti MCD, Bazzolli DMS, Kasuya MCM. 2012. Enrichment of Pleurotus ostreatus mushrooms with selenium in coffee husks. Food Chem, 131: 558-563.

Deepalakshmi K, Mirunalini S. 2014. Pleurotus ostreatus: An oyster mushroom with nutritional and medicinal properties J., Biochem Tech, 5(2): 718-726.

Doğan HH, Kurt F. 2016. New macrofungi records from Turkey and macrofungal diversity of Pozant1-Adana. Turk J Bot, 40: 209-217.

Doğan N, Doğan C, Hayoğlu G. 2017. Pleurotus ostreatus mantarının cips üretiminde kullanımı. Harran Tarım ve Gıda Bilimleri Dergisi, 21(2): 133-142.

Eren E, Pekşen A. 2016. Türkiye'de kültür mantarı sektörünün durumu ve geleceğine bakış. Turkish JAF Sci Technol, 4(3): 189-196.

Fontes-Vieira PA, Gontijo DC, Vieira BC, Fontes EAF, De Assunção LS, Leite JPV, Oliveira MGA, Kasuya MCM. 2013. Antioxidant activities, total phenolics and metal contents in Pleurotus ostreatus mushrooms enriched with iron, zinc or lithium. LWT- Food Sci Techno, 54: 421-425.

Gasecka M, Mleczek M, Siwulski M, Niedzielski P, Kozak L, 2015. The effect of selenium on phenolics and flavonoids in selected edible white rot fungi. LWT- Food Sci Techno, 63: 726-731.

Golak-Siwulska I, Kałużewicz A, Spiżewski T, Siwulski M, Sobieralski K. 2018. Bioactive compounds and medicinal properties of oyster mushrooms (Pleurotus sp.). Folia Hort, 30(2): 191-201.

Gomes-Correa RC, Brugnari T, Bratch A, Peralta RM, Ferreira ICFR. 2016. Biotechnological: nutritional and therapeutic uses of Pleurotus spp. (oyster mushroom) related with its chemical composition: A review on the past decade finding. Trends Food Sci Technol, 50: 103-117.

Honda T, Kai I, Ohi G. 1999. Fat and dietary fibre intake and colon cancer mortality: A chronological comparison between Japan and United States. Nutr Cancer, 33: 95-99.

Huang SJ, Lin CP, Tsai SY. 2015. Vitamin $\mathrm{D}_{2}$ content and antioxidant properties of fruit body and mycelia of edible mushrooms by UV-B irradiation. J Food Compos Anal, 42: 38-45.

Jaworska G, Bernas E, Mickowska B. 2011. Effect of production process on the amino acid content of frozen and canned Pleurotus ostreatus mushrooms. Food Chem, 125: 936-943.

Jaworska G, Pogon K, Bernas E, Duda-Chodak A. 2015. Nutraceuticals and antioxidant activity of prepared for consumption commercial mushrooms Agaricus bisporus and Pleurotus ostreatus. J of Food Qual, 38: 111-122.

Jesenak M, Urbancikova I, Banovcin P. 2017. Respiratory tract infections and the role of biologically active polysaccharides in their management and prevention. Nutrients, 9(779): 1-12.

Johnsy G, Sargunam SD, Dinesh MG, Kaviyarasan V. 2011. Nutritive value of edible wild mushrooms collected from the Western Ghats of Kanyakumari district. Bot Res Int, 4(4): 69-74.

Kalyoncu F, Oskay M, Sağlam H, Erdoğan TF, Tamer AÜ. 2010. Antimicrobial and antioxidant activities of mycelia of 10 wild mushroom species. J Med Food, 13(2): 415-419. 
Keleş A, Koca İ, Gençcelep H. 2011. Antioxidant properties of wild edible mushrooms. J Food Process Technol, 2: 130.

Keleş A, Genccelep H, Demirel K. 2017. Elemental composition of naturally growing wild edible mushroom. J Nat Prod Plant Resour, 7(4): 37-44.

Khan MDA, Amin SMR, Uddin MDN, Tania M, Alam N. 2008. Comparative study of the nutritional composition of oyster mushrooms cultivated in Bangladesh. Bangladesh J Mushroom, 2(1): 9-14.

Khan MDA, Tania M. 2012. Nutritional and medicinal importance of Pleurotus mushrooms: An overview. Food Rev Int, 28: 313-329.

Kırbağ S, Korkmaz V. 2014. Değişik tarımsal atıkların bazı kültür mantarı türlerinin besin değerleri üzerine etkisi. Artvin Coruh Uni J of Forest Fac, 15(2): 126-131.

Kibar B, Pekşen A. 2008. Modelling the effects of temperature and light intensity on the development and yield of different Pleurotus species. Agricultura Tropica et Subtropica, 41(2): 68-73.

Korkmaz V, Kırbağ S. 2014. Tarımsal ve endüstriyel atıklar üzerinde kültürü yapılan Pleurotus taksonlarının yağ asidi düzeylerinin tespit edilmesi. BEU J Sci, 3(2): 162-167.

Kortei NK, Odamtten GT, Obodai M, Appiah V, Akuamoa F, Adu-Bobi AK, Nana S, Annan Y, Nii J, Armah O, Acquah SA. 2014. Evaluating the effect of gamma radiation on the total phenolic content, flavonoids: and antioxidant activity of dried Pleurotus ostreatus ((Jacq. ex. Fr) Kummer) stored in packaging materials. Adv Pharm, 2014: 1-8.

Kues U, Liu Y. 2000. Fruiting body production in Basidomycetes. Appl Microbiol Biotechnol, 54: 141-152.

Kumar K. 2019. Nutraceutical potential and processing aspects of oyster mushrooms (Pleurotus species). Curr Nutr Food Sci, 15: 1-12.

Mahmoud KF, Amin AA, Salama MF, Seliem EI. 2015. Encapsulation of nano beta-glucan for preservation of functionality and targeted delivery of bioactive food component. Int J of ChemTech Res, 8(11): 587-598.

Mahmoud KF, Amin AA, Seliem EI, Salama MF. 2016. Nano capsulated polyphenol extracted from oyster mushroom (Pleurotus ostreatus), characterization and stability evaluation. Int J of PharmTech Res, 9: 103-113.

Manzi P, Aguzzi A, Pizzoferrato L. 2001. Nutritional values of mushrooms widely consumed in Italy. Food Chem, 73(3): 321-325.

Milovanovic I, Brceski I, Stajic M, Korac A, Vukojevic J, Knezevic A. 2014. Potential of Pleurotus ostreatus mycelium for selenium absorption. Scient World J, 2014: 1-8.

Morales D, Ruiz-Rodriguez A, Soler-Rivas C. 2018. The use of pressurized fluid technologies to obtain commercially interesting compounds from edible mushrooms. In: (Ed.: Taylor, J. C.). Advances in Chemistry Research (Volume 45). New York. Nova Science Publishers, Inc. pp: 1-42. ISBN: 978-1-53613-838-2.

Muthangya M, Mshandete A., Amana MJ, Hashim SO, Amelia K. 2014. Nutritional and antioxidant analysis of Pleurotus HK 37 grown on Agave sisalana saline solid waste. Int J Res Biochem Biophys, 4: 5-12.

Ndung'u SW, Otieno CA, Onyango C, Musieba F. 2015. Nutritional composition, physical qualities and sensory evaluation of wheat bread supplemented with oyster mushroom. American J Food Technol, 10(6): 279-288.

Niedzielski P, Mleczek M, Siwulski M, Rzymski P, Gasecka M, Kozak L. 2015. Supplementation of cultivated mushroom species with selenium: Bioaccumulation and speciation study. Eur Food Res Technol, 241: 419-426.

Nieto IJ, Chegwin C. 2013. The effect of different substrates on triterpenoids and fatty acids in fungi of the genus Pleurotus. J Chil Chem Soc, 58: 1580-1583.
Oyetayo VO, Ariyo OO. 2013. Micro and macronutrient properties of Pleurotus ostreatus (Jacq:Fries) cultivated on different wood substrates. Jord J Biological Sci, 6(3): 223226.

Oyetayo VO, Oyedeji RR. 2018. Assessment of microbial and sensory properties of bread fortified with mushrooms (Pleurotus ostreatus and Calocybe indica). J Adv Microbiol, 11(2): $1-7$

Özdal M, Gülmez Ö, Gür Özdal Ö, Algur ÖF. 2019. Antibacterial and antioxidant activity of mycelial extracts of different Pleurotus species. Food and Health, 5(1): 12-18.

Pardo A, Perona MA, Pardo J. 2005. Evaluación de nuevos materiales en la elaboración de sustratos específicos para el cultivo de Pleurotus ostreatus (Jacq. ex Fr.) Kummer. Cuad Fitopatol, 85: 77-83.

Pardo A, Perona MA, Pardo J. 2007. Nuevos materiales y tratamientos en la elaboración de sustratos para cultivo de Pleurotus ostreatus (Jacq. ex Fr.) Kummer. Cuad Fitopatol, 91: 7-13.

Pardo A, Perona MA, Pardo J. 2008. Evaluación de nuevos materiales en la elaboración de sustratos, 374.

Patel Y, Naraian R, Singh VK. 2012. Medicinal properties of Pleurotus species (oyster mushroom): A review. WJFPB, 3(1): 01-12.

Pekşen A, Bulam S, Üstün NŞ. 2016. Edible wild mushrooms sold in Giresun local markets. In: Özcanl1, M., Serin, H., Çalık, A. (eds.). 1st International Mediterranean Science and Engineering Congress (IMSEC 2016) Proceedings Book. Adana, Turkey. 26-28 October 2016. Çukurova University. pp: 3358-3362.

Pekşen A, Kaplan M. 2017. Ordu ilinin ekonomik öneme sahip yenilebilen doğa mantarları. Akademik Ziraat Dergisi, 6: 335-342.

Pelaes ACV, Goto AP, Hanai LN, Gomes-da-Costa SM, Filho BAA, Nakamura CV, Matumoto-Pintro PT. 2015. Microbiological, functional and rheological properties of low fat yogurt supplemented with Pleurotus ostreatus aqueous extract. LWT-Food Sci Technol, 64: 1028-1035.

Picornell-Buendía MR, Pardo-Giménez A, Juan-Valero D, Arturo J. 2016. Agronomic qualitative viability of spent Pleurotus substrate and its mixture with wheat bran and a commercial supplement. J Food Quality, 39(5): 533-544.

Piska K, Sułkowska-Ziaja K, Muszyńska B. 2017. Edible mushroom Pleurotus ostreatus (oyster mushroom) - its dietary significance and biological activity. Acta Sci Pol Hortorum Cultus, 16(1): 151-161.

Ragunathan R, Swaminathan K. 2003. Nutritional status of Pleurotus spp. grown on various agro-wastes. Food Chem, 80: 371-375.

Rathore H, Prasad S, Sharma S. 2017. Mushroom nutraceuticals for improved nutrition and better human health: A review. PharmaNutrition, 5: 35-46.

Regula J, Krejpcio Z, Staniek H. 2016. Iron bioavailability from cereal products enriched with Pleurotus ostreatus mushrooms in rats with induced anemia. Ann Agric Environ Med, 23(2): 310-314.

Reis FS, Barros L, Martins A, Ferreira ICFR. 2012. Chemical composition and nutritional value of the most widely appreciated cultivated mushrooms: An interspecies comparative study. Food Chem Toxicol, 50: 191-197.

Reis FS, Martins A, Vasconcelos MH, Morales P, Ferreira ICFR. 2017. Functional foods based on extracts or compounds derived from mushrooms. Trends Food Sci Technol, 66: 4862.

Royse DJ. 2014. A global perspective on the high five: Agaricus, Pleurotus, Lentinula, Auricularia \& Flammulina. In: Singh, M. (ed.). Proceedings of the $8^{\text {th }}$ International Conference on Mushroom Biology and Mushroom Products, New Delhi, India. pp: 1-6. 
Sanchez C. 2010. Cultivation of Pleurotus ostreatus and other edible mushrooms. Appl Microbiol Biotechnol, 85: 13211337.

Sari M, Prange A, Lelley JI, Hambitzer R. 2017. Screening of beta-glucan contents in commercially cultivated and wild growing mushrooms. Food Chem, 216: 45-51.

Sesli E, Denchev CM. 2014. Checklists of the myxomycetes, larger ascomycetes, and larger basidiomycetes in Turkey. $6^{\text {th }}$ edn Mycotaxon Checklists Online (http://www.mycotaxon.com /resources/checklists/sesli-v106-checklist.pdf): 1-136.

Sevindik M, Akgül H, Günal S, Doğan M. 2016. Pleurotus ostreatus' un doğal ve kültür formlarının antimikrobiyal aktiviteleri ve mineral madde içeriklerinin belirlenmesi. Kastamonu Uni J of Forest Fac, 16(1): 153-156.

Sevindik M, Bal C, Akgül H. 2018. Comparison of antioxidant potentials of the wild and cultivated forms of edible Pleurotus ostreatus and Agaricus bisporus mushrooms. Turk J Life Sci, 3(2): 263-266.

Süfer Ö, Bozok F, Demir H. 2016. Usage of edible mushrooms in various food products. Turkish JAF Sci Technol (TURJAF), 4(3): 144-149.

Synytsya A, Míčková K, Jablonský I, Sluková M, Čopíková J. 2008. Mushrooms of genus Pleurotus as a source of dietary fibres and glucans for food supplements. Czech J Food Sci, 26: 441-446.

Synytsya A, Míčková K, Synytsya A, Jablonský I, Spěváček J, Erban V, Kovarikova E, Čopíková J. 2009. Glucans from fruit bodies of cultivated mushrooms Pleurotus ostreatus and Pleurotus eryngii: Structure and potential prebiotic activity. Carbohyd Polym, 76(4): 548-556.

Taofiq O,Heleno SA, Calhelha RC, Alves MJ, Barros L, Barreiro MF, González-Paramás AM, Ferreira ICFR. 2016. Development of mushroom-based cosmeceutical formulations with anti-1nflammatory, anti-tyrosinase, antioxidant, and antibacterial properties. Molecules, 21(137): 21-12.

Teichmann A, Dutta PC, Staffas A, Jagerstad M. 2007. Sterol and vitamin $\mathrm{D}_{2}$ concentrations in cultivated and wild grown mushrooms: Effects of UV irradiation. LWT-Food Sci. Technol, 40: 815-822.

Tolera KD, Abera S. 2017. Nutritional quality of oyster mushroom (Pleurotus ostreatus) as affected by osmotic pretreatments and drying methods. Food Sci Nutr, 5: 989 996.
Turfan N, Pekşen A, Kibar B, Ünal S. 2018. Determination of nutritional and bioactive properties in some selected wild growing and cultivated mushrooms from Turkey. Acta Sci Pol Hortorum Cultus, 17(3): 57-72.

Üstün NŞ, Bulam S, Pekşen A. 2018. The use of mushrooms and their extracts and compounds in functional foods and nutraceuticals. In: Türkmen, A. (ed.). 1. International Technology Sciences and Design Symposium (ITESDES) Proceeding Book. Giresun, Turkey. 27-29 June 2018. Giresun University. pp: 1205-1222.

Vishwakarma P, Singh P and Tripathi NN. 2017. In-vitro antioxidant activity and nutritional value of four wild oyster mushroom collected from North-Eastern Part of Uttar Pradesh. Mycosphere, 8(4): 592-602.

Wakchaure GC, Shirur M, Manikandan K, Rana L. 2010. Development and evaluation of oyster mushroom value added products. Mushr Res, 19(1): 40-44.

Wang D, Sakoda AK, Suzuki M. 2001. Biological efficiency and nutritional values of Pleurotous ostreatus cultivated on spent beer grain. Bioresour Technol, 78: 293-300.

Woldegiorgis AZ, Abate D, Haki GD, Ziegler GR. 2014. Antioxidant property of edible mushrooms collected from Ethiopia. Food Chem, 157: 30-36.

Wu Y, Choi MH, Li J, Yang H, Shin HJ. 2016. Mushroom cosmetics: The present and future. Cosmetics, 3(3): 22.

Yang JH, Lin HC, Mau JL. 2001. Non-volatile taste components of several commercial mushrooms. Food Chem, 72: 465-471.

Yılmaz A, Yıldız S, Tabbouche S, Kılıç AO, Can Z. 2016. Total phenolic content, antioxidant and antimicrobial properties of Pleurotus ostreatus grown on lime (Tilia tomentosa) leaves. Hacettepe J Biol Chem, 44(2): 119-124.

Yılmaz A, Yıldız S, Kılıç C, Can Z. 2017. Total phenolics, flavonoids, tannin contents and antioxidant properties of Pleurotus ostreatus cultivated on different wastes and sawdust. Int. J Sec Metabolite, 4(1): 1-9.

Yildiz S, Yildiz ÜC, Gezer ED, Temiz A. 2002. Some lignocellulosic wastes used as raw material in cultivation of the Pleurotus ostreatus culture mushroom. Process Biochem, 38: 301-306. 